\title{
Factors Behind the Rise and Fall of Farmland Prices: A Preliminary Assessment
}

\author{
Michael T. Belongia
}

$\mathrm{T}$

HE current debt problems facing many farmers can be attributed, in large measure, to the factors that produced the spectacular rise in farmland prices during the 1970s and their precipitous decline since 1981. After increasing at a 5.6 percent average annual rate between 1951 and 1971, the growth in the price of U.S. farmland accelerated dramatically: farmland prices rose at a 14.0 percent average annual rate from 1972 to 1981. Because land prices were rising faster than the rate of inflation at that time, the collateral base against which farmers could borrow increased significanty. Moreover, the availability of subsidized credit for famland purchases and certain tax advantages enhanced farmland ownershp as an investment. Finally, repeated warnings about impending world food shortages suggested that retums to famand in production would rise ${ }_{f}$ further increasing the demand for it.'

Recently, however, the price of farmland has been falling. Since its 1981 peak, the price of famland in the United States has declined at a 5.1 percent average annual rate, bringing famland prices near their 1979 values of course, as land prices have fallen, the value

Michael T. Belongia is a senior economist with the Federal Resenve Bank of St. Louis. Jude L. Naes, Jr, provided research assistance. J. Bruce Bullock, James A. Chalfant, David Ervin, E. C. Pasour, Jr, Daniel A. Sumner and James Seagraves provided comments on an earlier draft of this paper. Any remaining errors or omissions are the responsibility of the author.

FFor example, as late as 1981 , just two years prior to when the PIK program was implemented to reduce large and growing surplus grain stocks, the fitle of USDA's Yearbook of Agriculture was Witt There Be Enough Food? of farm equity has declined, and the ability of farmers to secure additional credit has been diminished.

Many studies of the genexal movement in farmland prices have been conducted in the past. ${ }^{2}$ Most of these studies, however, predate the recent-period decline in land prices. The purpose of this article is to examine the theoretical determinants of fammand values and to detemine whether they can account for the rise and decline of famland prices in recent years.

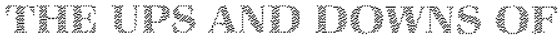

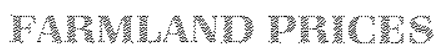

The data plotted in chart 1 show the behavior of farmland prices in the postwar period. "The first point to note is that the price of famland generally has increased at a rate highes than the rate of inflation, as measured by the GNP deflator. Moreover, the variabilm

\footnotetext{
"Explanations for rising land prices include the accumutated savings from farm income and accumulated real estate debt. variatons in farm income, increases in the general price level and increases in the provisions of commodity price support programs. See Shalit and Schmitz (1982), Herdt and Cochrane (1966) and Castle and Hoch (1982). Other studies of farmand prices include Tweeten and Martin (1966), Phipps (1984) and Reinsel and Reinsel (1979). A recent paper that provides a descriptive overview of the initial year of the recent land price decline is by Scott (1983). Doll, Widdows and velde (1983) have surveyed the theoretical and empirical literature on land prices.

The index is based on an average of farmand prices, per acre, in the 48 contiguous states. Until 1975 , the prices were those existing on March 1. From 1976-81, February 1 prices were used. April 1 is the basis for 1982-84 prices. See Economic Report of the President (1985), p. 341 .
} 
Chart 1

\section{Farmland Prices and Inflation}

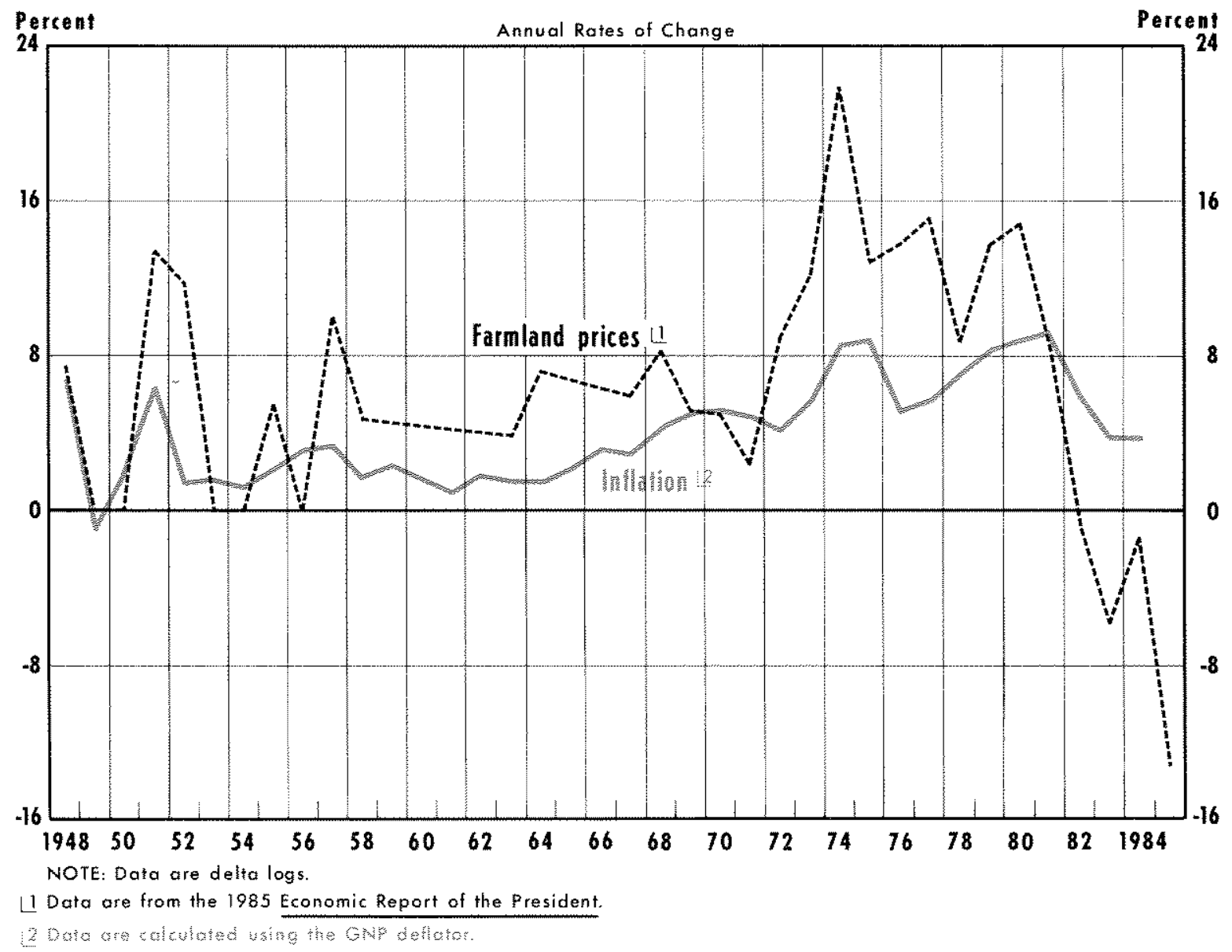

ity in farmland price growth appears to be considerably greater than the variability of increases in the general price level. Although the growth of land prices and the rate of inflation obviously are correlated, the chart suggests that land prices may be affected by additional factors. Chart 1 , however, merely summarizes what has occurred to land prices and does not tell us what has produced this result. For inferences concerning what these causal factors might be: we lum to a simple model of land prices.

\footnotetext{
The standard deviations of the growth rate of land prices and the rate of inflation are, respectively, 6.5 and 2.6. Average values for the annual growth rate of land prices and the rate of inflation over the 1948-85 (through 1984 for inflation) sample are 6.0 and 4.1 percent, respectively.
}

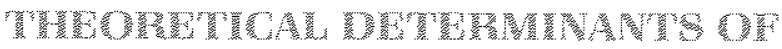

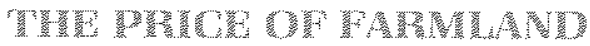

Although the supply of land for use in farming has some price elasticity and will change in response to factors that affect its returns in other uses, it is convenient for our purposes to examine primarily those factors that change the demand for farmland." Therefore, we assume that the total amount of land available for farming is constant. Because we have ruled out changes in the supply of land, changes in the price of

\footnotetext{
5Sigler (1966) notes the common fallacy, which argues that the supply of land is perfectly inelastic. While this is not even strictiy true for the total supply of land, the important consideration is thow easily land can be shiffed from other uses to agricultural production. In this sense, the supply of land certainly is not perfectly inelastic.
} 
farmland must arise from changes in the demand for farmland. The section that follows explains the factors that, theoretically, should influence the demand for farmland.

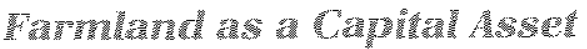

The price of land always will be determined by two factors: the net return to land employed in its "best" alternative use and the interest rate or rates that are used to discount these net retums to the present. For purposes of illustration, consider an acre of land best suited to corn production that will yield 100 bushels at a price of $\$ 3$ per bushel; total receipts, then, are $\$ 300$. If variable costs in producing com each year - the costs of fertilizer, seed, the use of equipment and labor were $\$ 200$, the residual return to the land would be $\$ 100$ each year. In the absence of expected inflation, increased productivity and special knowledge about future economic shocks, $\$ 100$ would be the net return expected in all future years as well.

This net expected annual retumn to the owner of an acre of farmland used to produce corn will be evaluated against the stream of returns accruing to other investments. That is, the farmer will ask himself what amount, if invested elsewhere at the current interest rate, would yield an annual return of $\$ 100$. A rational farmer-investor, ceteris paribus, will not pay more for the acre of farmland than the amount of this alternative investment.

This acre of land will sell for its capitalized value, that is, the present discounted value of all future eamings from the land. This relationship can be expressed as:

(1) land price $=$ net returns $\div$ interest rate.

If the interest rate is currently 5 percent, the value of the land would be $\$ 2,000(\$ 100 \div 0.05)$; this is the maximum price that an investor would pay for the land. If the land price were higher, for example, $\$ 2,500$, it would be irrational and unprofitable to purchase the land; investing the $\$ 2,500$ in bonds or stocks yielding 5 percent would earn more $\$ \$ 125$ ) than the $\$ 100$ return to land employed in farming.

It is clear from equation 1 that, for a given interest rate, the price of farmland will change whenever there are changes in the expected real net returns to farming. Expected net returns will change if the expected

This representation of an asset's capital value can be found in virtually all economics texts. Implicit assumptions are an infinite planning horizon and a constant real interest rate. receipts from selling corn or the expected variable cost of producing corn are altered.

In assessing changes in real returns, we are interested in changes in receipts or costs apart from those changes in nominal values associated with the general trend in inflation. Expected real receipts would rise, for example, if yields per acre were increased and the demand for corn were relatively elastic in the relevant range, or if government price supports were raised. The expected real cost of producing conn is affected by changes in the relative prices of fuel, fertilizer, crop insurance, water and a variety of other factors employed as inputs in the production process. In either case, for a given rate of interest, changes in expected real receipts or costs will produce changes in the expected net returns to investment in farmland relative to the returns avalable on other investments. When this occurs, land prices will change to bring the rate of return for farmland back into line with other alternative rates.

Changes in govemment farm programs have affected land prices by raising the expected net income associated with farming. Direct income transfers based on target prices have increased the expected income from crop production by allowing farmers to sell eligible crops at the market price and then receive a direct payment equal to the quantity of a crop sold multiplied by the difference between the market price and target price. Loan rates, which establish a price floor for crops, also increase expected income by eliminating the risk associated with market prices falling below the support level. Because these program benefits increase the expected income from farming, they are capitalized into land values.

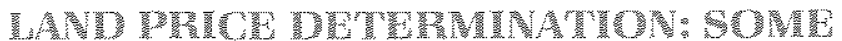

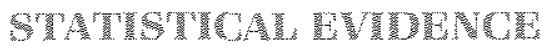

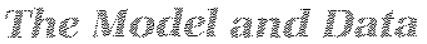

The relative impacts on land prices from the economic relationships discussed above can be assessed in a simple statistical model. Based on the previous discussion, the annual percentage change in the price of farmland can be estimated as:

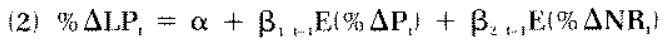

$$
\begin{aligned}
& +\beta_{3} \% \Delta r+\varepsilon_{1}{ }^{*}
\end{aligned}
$$

This result has been demonstrated by Harris (1977). Boehlje and Griffin (1979), Gardner (1981), Pasour (1980) and Belongia (1983).

spercentage changes $(\% \Delta)$ are calculated as first differences of logarittinms, muitiplied by 100 . 


\section{Table 1}

\section{Assessing the Contribution of Alternative Factors to the Growth of Land Prices}

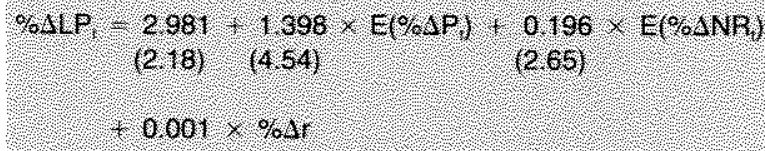

NOTE I statstics hoarentheses:

Equation 2 states that the ate of change in farmand prices $(\% \Delta L P)$ will be determined by the expected future rate of inflation $\left[_{\mathrm{f}, \mathrm{E}} \mathrm{E}\left[\% \Delta \mathrm{P}_{\mathrm{t}}\right)\right]$, expected growth in real net returns from farming $\left.l_{1,1} E\left(\% \Delta N R_{1}\right)\right)$, which includes cash receipts and government payments minus variable costs, and the percentage change in the real rate of return on an alternative investment $(\% \Delta r)$. Note that, in contrast to many previous empirical studies, this equation is based on ex ante expectations rather than actual ex post data. Although using estimated proxies for unobserved expectations variables introduces the problem of measurement error, ex post data values have little to do with the $e x$ ante decision to buy or sell farmland.

Expectations for future inflation and real returns are assumed to be three-year moving averages of past actual values. Exact variable definitions and data sources appear in the appendix to this article. Based on the earlier discussion of how land prices are determined, expected inflation and the expected growth in real net returns to farm production should be positively related to land values. The expected sign on the percentage change in the real opportunity cost of capital, $\% \Delta r$, is negative.

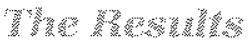

The results of estimating equation 2 using anrual data from 1955 through the 1981 peak in land prices

Ghanges in expected inflation are linked, in theory, to transitory changes in the real rate of interest. This possibility introduces the potential for a collinearity problem in the estimating equation if $\mathrm{E}(\% \Delta \mathrm{P})$ and $\% \Delta \mathrm{r}$ are correlated. Their simple correlation coefficient (0.06), however, is not significantly different from zero. are shown in table 1 . The model explains 49 percent of the variation in the growth of land prices.

The results show, as expected, that increases in the growth of expected real net returns and an increase in expected future inflation tend to increase the rate at which farmland prices increase. The sizes of these estimated coefficients and actual changes in expected inflation and retums offer more insight. While a 1 percentage-point increase in expected inflation has an effect on the rate of land price appreciation about seven times larger than a similar increase in expected receipts, expected receipts exhibit considenably larger changes over time than expected inflation. For example, expected inflation ranged between 1.4 and 8.1 percent over the 27-year sample, whereas expected growth in real net returns was as high as 24 percent in 1974 and as low as -25 percent in 1977 . Considered together, these coefficients and the raw data suggest that expected inflation is a determinant of the longrun trend growth of nominal land prices and expected net retutns, which are subject to considerable year-toyear variability, are a significant factor in producing short-run variations in the growth of land prices.

It also is interesting to note that the coefficient on expected inflation is not significantly different from one, implying that expected inflation was completely reflected in land prices. From an economic viewpoint, this result indicates that farmland was a perfect hedge against inflation over the estimation period. Finally, the growth in land prices is not significantly related to the regression's other variable, the real rate of interest.

Examining the in-sample fit of the model can be used as a guide to the model's likely usefulness in detemining its ability to predict the future behavior of land prices. For example, if the model's errors are randomly distributed through time and are neither one-sided nor of larger absolute value in recent periods, one might infer that it represents a reasonably accurate description of the process through which changes in land prices are determined. Conversely, if recent errors are significantly larger or one-sided, this information may imply that the model is misspecified. As chart 2 indicates, the in-sample errors of equation 2 over the 1955-81 period appear to be fandomly distributed, despite the volatile behavior of land prices. Two of the residuals are more than twice the size of the regression's standard error $(6.96)$.

\section{Or}

The results in table 1 explain the behavior of land prices through their 1981 peak. In view of the variety of 
Chorf 2

\section{Residuals from Equation 2}

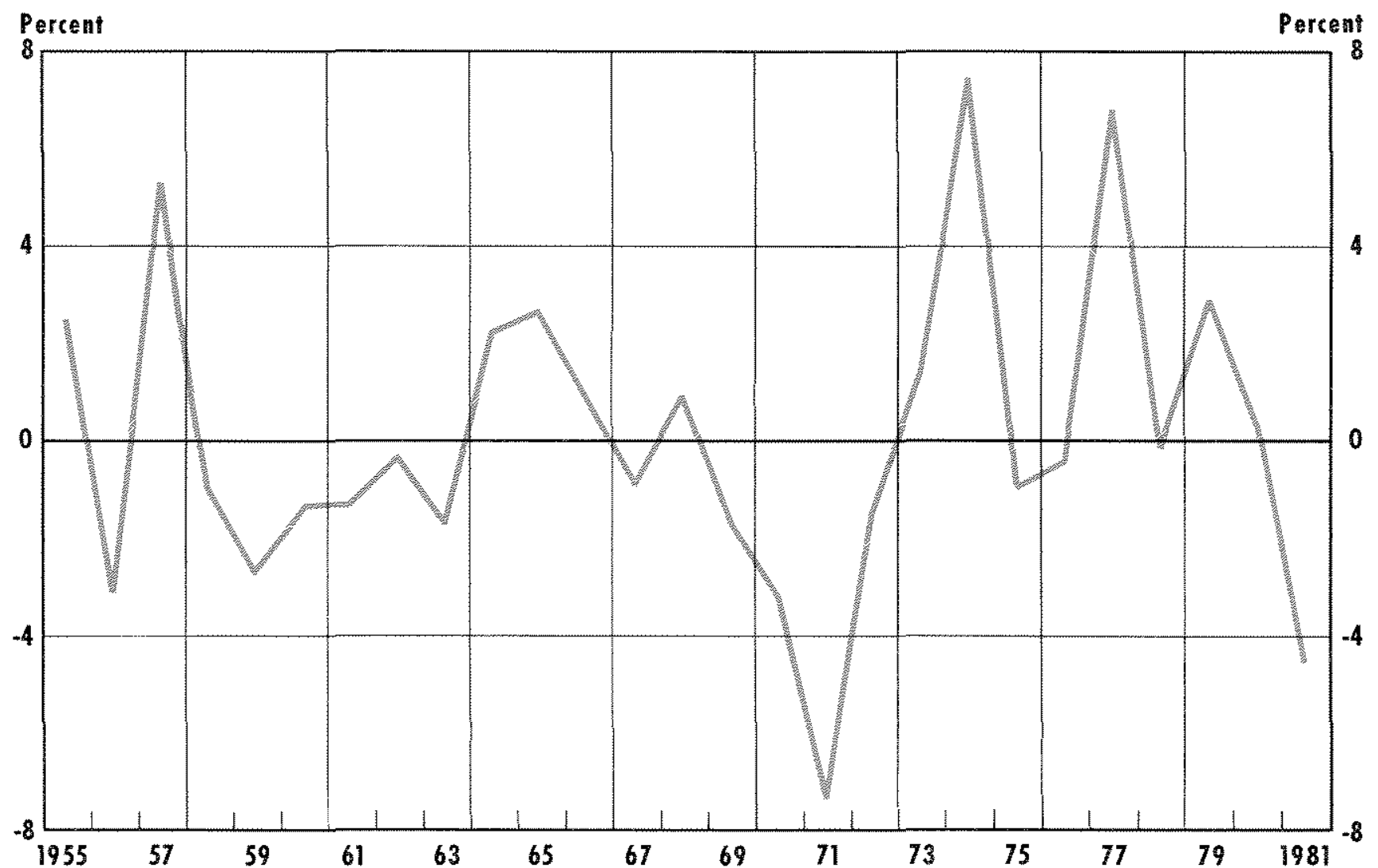

explanations that have been offered for the sharp drop in land prices, it is interesting to investigate whether the model will reveal any one variabie as a dominant factor in the recent land price decline.

This experiment is conducted by using the estimated coefficients in table 1 and actual values for the variables in equation 2 to project values for the percentage change in farmland prices for 1982-85. These projections and the out-of-sample emors are reported in table 2 .

The table clearly shows that the variables in equation 2 do a poor job of explaining the sharp decline in farmland prices since 1981 . While the model projects slower growth for land prices, it does not explain the actual reductions in the levels of land prices that have occurred in each of the last four years.

A number of possible explanations for this poon simulation performance can be offered. Equation 2 could be misspecified in a variety of ways, including the omission of variables important to the land price decline. A more likely explanation is that the variables included are subject to considerable measurement error. Since they are intended to reflect expectations, they are not observable directly and may not follow the assumed moving average process. Moreover, expectations may be asymmetric: that is, expectations may be based on a long history of past data while inflation and government payments are rising, but take on a short history when these variables are declining. This effect may be particularly true since 1981 , when proposals to cut government's suppost of agriculture significantly began to emerge. The evidence presented in the bottom half of table 2 lends some support to this conjecture by indicating that ony expected returns from farming have moved in a direction and changed by a magnitude consistent with the land price decline, while expected inflation has ad- 


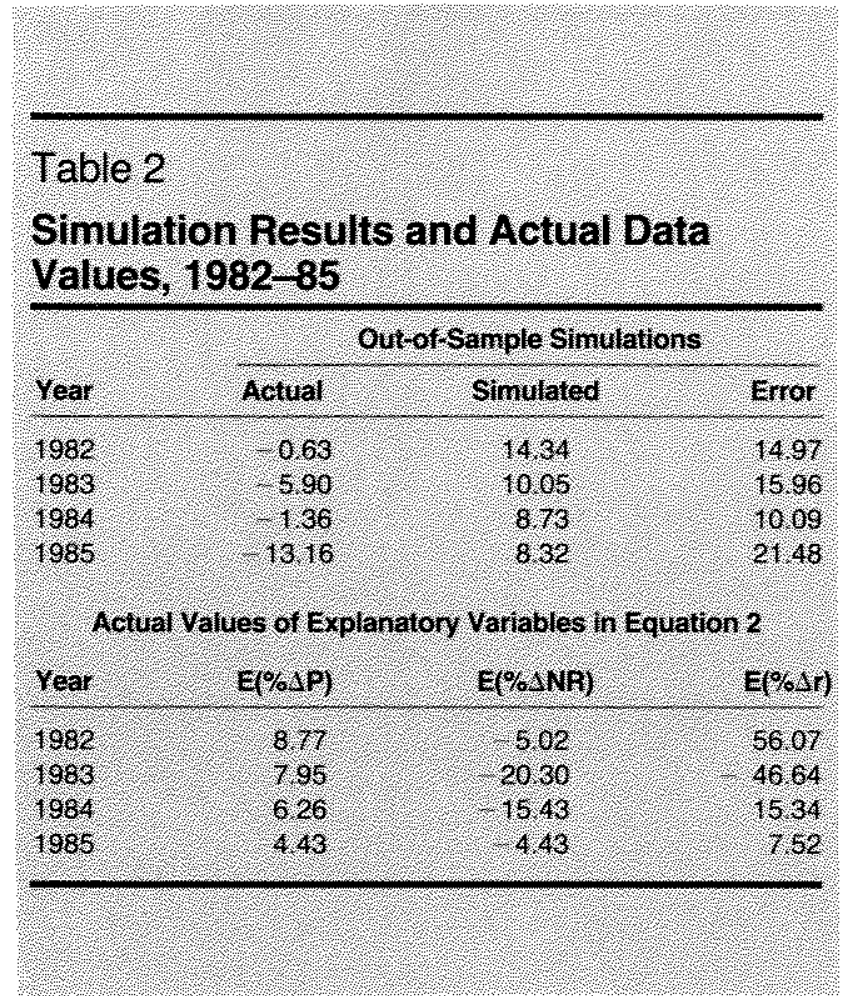

justed slowly to lower actual inflation. Thus, while the drop in expected real returns is consistent with the land price decline, it is largely offset by movements in the other variables that are smaller or in the wrong direction.

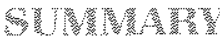

The price of farmland generally has followed the rollercoaster of expectations about future inflation and income from farming. The influences of these expectations were assessed in conjunction with other factors that affect the demand for farmland as an input to farm production. A simple model of land prices was constructed based on variables that were expected to influence the net retums to land used in farming and the retums and costs of holding land as an investment relative to the returns on other investments. The results of estimating a statistical model derived from these arguments showed that expected inflation and expected growth in real net returns to farm production were significant factors in determining the rate of increase in land values during the 1970 s. Even with the recent sharp reductions in expected returns, however, the model does not explain the rapid decline in farmland values since 1981. A likely reason for this failure, when contrasted with the model's in-sample performance, is error in the measurement of expectations concerning the future paths of inflation, returns and the real interest rate.

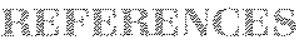

Belongia, Michael T. "Agricultural Price Supports and Cost of Production: Comment," American Joumal of Agricultural Economics (August 1983), pp. 620-22.

Boehlje, Michael, and Steven Griffin. "Financial Impacts of Government Support Price Programs," American Joumal of Agricultural Economics (May 1979), pp. 285-96.

Castle, Emery N., and living Hoch. "Farm Real Estate Price Com" ponents, 1920-78," American Journal of Agricultural Economics (February 1982), pp. 8-18.

Doll, John P., Richard Widdows and Paul D. Velde. "A Critique of the Literature on U.S. Farmiand Values," ERS Staff Report No. AGES830124 (U.S. Department of Agriculture, January 1983).

Economic Report of the President. (U.S. Government Printing Office, Febfuary 1985).

Gardner, Bruce L. The Governing of Agriculture (The Regents Press of Kansas, 1981).

Harris, Duane G. "Inflation-Indexed Price Supports and Land Values," American Journal of Agricultural Economics (August 1977), pp. 489.95.

Herdt, Robert W., and Willard W. Cochrane. "Farm Land Prices and Farm Technological Advance." Journal of Farm Economics (May 1966), pp. 243-63.

Holland, A. Steven. "Real Interest Fates: What Accounts for Their Recent Rise?" this Review (December 1984), pp. 18-29.

Pasour, E. C., Jr. "Cost of Production: A Defensible Basis for Agricuttural Price Supports?" American Joumal of Agricultural Economics (May 1980), pp. 244-48.

Phipps, Tim T. "Land Prices and Farm-Based Retums." American Journal of Agricultural Economics (November 1984), pp. 422-29.

Reinsel, Robert D., and Edward 1. Reinsel. "The Economics of Asset Values and Current Income in Farming," American Joumal of Agricultural Economics (December 1979), pp. 1093-97.

Scoth, John T., Jr. "Factors Affecting Land Price Dectine," American Joumal of Agricultural Economics (November 1983), pp. 796-800.

Shalit, Hain, and Andrew Schmitz. "Farmland Accumulation and Prices," American Journal of Agricultural Economics (November 1982), pp. 710-19.

Stigler, George J. The Theory of Price, 3rd ed. (The Macmillan Company, 1966).

Tweeten, Luther G., and James E. Martin. "A Methodology for Predicting U.S. Farm Real Estate Price Variation," Journal of Farm Economics (May 1966), pp. 378-93.

U.S. Department of Agriculture. Will There Be Enough Food? The 1981 Yearbook of Agriculture (GPO, 1981).

\section{APDEREDX}

\section{Data Sources ring Variable Descriptions}

Land prices were measured by an index of farmland values for the 48 states reported in the Economic Report of the president (1985), p. 341. Inflationary expectations were represented by a three-vear moving 
average of past actual inflation as measured by growth in the GNP deflator. Expected real net retums from farming were assumed to be a threeyear moving average of past growth in actual returns; this assumption was based on the notion that, since random shocks to production are the largest source of price change but cannot be predicted in advance, expected returns follow a random walk around some trend. Net returns were defined to be receipts from farm marketings plus government payments minus variable costs and were obtained from the Economic Report of the President, p. 338 . Real retums are net returns deflated by the GNP deflator. The $e x$ ante real rate of interest was measured as the nominal interest rate on one-year Treasury securities in the fourth quarter of year $t-1$ minus the one-year-ahead expectation of inflation as measured by the December, year $\mathbf{t - 1}$, Livingston survey; see Holland (1984) for further details. The data used to estimate equation 2 are annual series from 1955-81. 